\title{
A Contrastive Study on Korean and Cia-Cia Language Vowels Based on an Acoustic Experiment
}

\author{
Achmad Rio Dessiar \\ Department of Korean Language and Literature, Kyungpook National University, South Korea \\ Email: desiar@ugm.ac.id
}

\begin{abstract}
The Cia-Cia language, which spoken by around 79.000 people in the Bau-Bau area of Buton Island, does not have its own writing system. In 2009, the Korean alphabet, Hangeul, was approved by the Bau-Bau city government for transcribing Cia-Cia, owing to the similarity of phonemes in Korean to those in Cia-Cia. This research aimed to compare the acoustics of monophtongs in the Korean and Cia-Cia languages with an experimental phonetic approach, and to discuss writing system problems in Cia-Cia when adopting the Korean writing system.

Based on the classification, the Cia-Cia vowels /i, e, a, u, and o/ are equivalent to the Korean vowels / 0 ([i]), 에 ([e]), 아 ([a]), 우 ([u]), 오 ([o] )/. However, there are two Korean vowels that have no Cia-Cia equivalents namely, /으/([i]) and /어/ ([ə]]).

In general, the vowel equivalents between the two languages have significant differences in terms of their acoustic characteristics. Nonetheless, unlike other vowel equivalents, the Cia-Cia vowel $/ \mathrm{u} /$ and Korean vowel / 우/ ([u]) when pronounced show similar phonetic features in terms of position and oral cavity opening level. In contrast, the Cia-Cia vowel /a/ and Korean vowel $/$ 아/ ([a]) when pronounced are shown to have the same oral cavity opening level, but different tongue positions.

The use of the vowel /으/([i]) in Hangeul writing in transcribing particular Cia-Cia wordsis a unique feature of Korean grammar. This renders some transcriptions different to the pronunciation of the source Cia-Cia word. This is because of the limitations of Korean syllables, which, unlike Cia-Cia words, are not able to be written as double consonants.
\end{abstract}

Keywords: monophtong, acoustic phonetics, experimental phonetics, Korean, Cia-Cia, Hangeul letters, contrastive research

\section{INTRODUCTION}

This research aims to compare single Korean and Cia-Cia vowels with an experimental phonetic approach. In this research, the vowel systems and phonetic characteristics were analyzed and the similarities and differences investigated. It also examines the vowel writing system in the Cia-Cia language when adopting the Korean writing system and investigates associated vowel transcription problems.

Indonesia is a country rich not only in its natural resources, but also in its ethnic and cultural diversity. According to the Central Agency for Statistics (Badan
Pusat Statistik-BPS)1) survey data, Indonesia has more than six hundred ethnic groups scattered throughout the Indonesian archipelago. Among the many ethnic groups in Indonesia, the Cia-Cia are one of its ethnic minority groups with a population of around 79000 people2), most of whom live in the Bau-Bau area, Buton Island, Southeast Sulawesi, Indonesia. The native language of this ethnic group is Cia-Cia, which belongs to the Austronesian language family (Safitri 2014).

Cia-Cia, despite being used as a spoken language by the Cia-Cia people, does not have its own writing 
system. As a result, the practice has been to write the CiaCia language using letters sourced from other languages. Concomitant with the growth of Islamic influence in Sulawesi, from Islam's arrival in the 16th century, under the Sultanate of Buton, Cia-Cia was written in modified Arabic letters called Buri Wolio letters (the official letters of the Wolio language)3), and from the beginning of the 19th century most letters were written in Roman letters, which has been adopted officially for the written Indonesian language.

The results of the International Symposium of Indonesian Manuscripts, organized by the Bau-Bau government in 2005, stated that many languages of the ethnic minorities in Southeast Sulawesi area were on the edge of extinction. One of the languages considered to be facing a crisis of extinction is Cia-Cia, as evidenced by the ever-diminishing number of people who can speak Cia-Cia. The former mayor of Bau-Bau, Amirul Tamim emphasized that one of the reasons why Cia-Cia was close to extinction was that there were no suitable letters to write Cia-Cia manuscripts. Buri Wolio and Roman letters were considered unable to represent some CiaCia phonemes, so in 2008 the Bau-Bau city government accepted the offer initiated by the Hunmin Jeongeum Society of Korea to create a Cia-Cia preservation program. It offers Korean letters called Hangeul considered suitable to be able to transcribe Cia-Cia since the phonemes found in Korean were considered to be similar to Cia-Cia. In 2009 the Bau-Bau city government approved Hangeul letters for transcribing Cia-Cia in order to prevent CiaCia becoming extinct.

Before Hangeul letters were adopted to transcribe Cia-Cia, those researching Cia-Cia were only Indonesian researchers. The research conducted by Mustafa Abdullah (1991) can be said to be the first domestic research to research Cia-Cia as a whole and his work has become a reference for other researchers who are investigating CiaCia. From 2009 however, Korean and Cia-Cia contrastive research commenced and was largely undertaken by Korean scholars. These researchers included Jeon, Lee (2009), Jeon (2010), Kim (2012), and Dessiar (2020, 2021). To date, the form of research uses a phonological approach comparing the phonemes of those two languages. This research however, is different from the previous research as it was conducted with an experimental phonetic approach. To date there has been no contrastive research found in Cia-Cia and Korean using this approach. Further, this research also discusses the vowel writing system problem in Cia-Cia language. The intent of his research is that the findings can be used as a reference for improving Cia-Cia transcription using Hangeul letters.

\section{METHOD}

The analysis of the phonetic characteristics of Cia-Cia and Korean single vowels, involved twenty native $\mathrm{Cia}-\mathrm{Cia}$ speakers and twenty native Korean speakers as informants. The gender composition of the speaker group was balanced, namely ten men and ten women, respectively. The Cia-Cia informants were indigenous people in their 20s, born and raised in Surawolio Subdistrict, Bau-Bau City and could speak Cia-Cia fluently. The reasons for the specific selection of speakers from Surawolio Subdistrict was that apart from being the center of Cia-Cia tribal settlement, the Hangeul letter recognition program was first carried out in this subdistrict. Additionally, the teaching of Hangeul and the use of Hangeul letters in public facilities are ongoing.

On the other hand, the Korean informants were students of Kyungpook National University (KNU) in their 20s, born and raised in Daegu City. The reason for using Korean speakers from Daegu City in their 20s as the research subjects is) that as Korean single vowel speakers, the Daegu speakers in their 20s were almost indistinguishable from the Seoul metropolitan area speakers in their 20s (Sin, et al. (2006) and Jang (2006)). Daegu speakers in their 20 s then are able to represent Korean informants in the case of Korean single vowel speakers. Informant data is presented in Tables 1 and 2.

The research objects were Cia-Cia and Korean single vowels. Based on previous research, there are five Cia-Cia single vowels consisted of / a /, / i /, / o /, $/ \mathrm{u} /$, and / e / and five Korean single vowels comprise

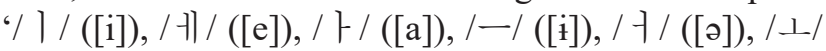
([o]), / T/ ([u] )'. The difference in the vowel position in the vocabulary can cause phonetic differences, so this research focuses on the vowels at the beginning of a word. The data used in this research were voice recording data from the informants who had been selected based on age, gender, origin, and education level. The Korean vowel data were obtained from the recorded data of Korean informants who pronounced Korean vocabulary while the Cia-Cia vowel data were obtained from the recorded data of Cia-Cia informants who pronounced Cia-Cia vocabulary. The following are Korean and CiaCia vocabulary data used in this research.

In this research, high quality sound data was needed so that it could be analyzed using this experimental phonetic approach. To this end, the recording of informants was carried out in a quiet room. To reduce noise during the recording process, electronic devices that could interfere with the recording of sounds such as air conditioning, computers, and other equipment were turned off. 
Table 1. Cia-Cia Informant Data

\begin{tabular}{|l|l|l|l|l|}
\hline No & Informant Code & Age & Gender & Origin \\
\hline 1 & fc1 & 19 & F & Sorawolio \\
\hline 2 & fc2 & 20 & F & Sorawolio \\
\hline 3 & fc3 & 30 & F & Sorawolio \\
\hline 4 & fc4 & 19 & F & Sorawolio \\
\hline 5 & fc5 & 21 & F & Sorawolio \\
\hline 6 & fc6 & 21 & F & Sorawolio \\
\hline 7 & fc7 & 20 & F & Sorawolio \\
\hline 8 & fc8 & 20 & F & Sorawolio \\
\hline 9 & fc9 & 20 & F & Sorawolio \\
\hline 10 & fc10 & 23 & F & Sorawolio \\
\hline 11 & mc1 & 19 & M & Sorawolio \\
\hline 12 & mc2 & 25 & M & Sorawolio \\
\hline 13 & mc3 & 26 & M & Sorawolio \\
\hline 14 & mc4 & 19 & M & Sorawolio \\
\hline 15 & mc5 & 24 & M & Sorawolio \\
\hline 16 & mc6 & 21 & M & Sorawolio \\
\hline 17 & mc7 & 20 & M & Sorawolio \\
\hline 18 & mc8 & 20 & M & Sorawolio \\
\hline 19 & mc9 & 24 & M & Sorawolio \\
\hline 20 & mc10 & & & \\
\hline & & Sorawolio \\
\hline
\end{tabular}

Table 3. Korean and Cia-Cia vocabulary data

\begin{tabular}{|c|c|c|c|}
\hline \multicolumn{2}{|c|}{ Cia-Cia vocabulary } & \multicolumn{2}{|c|}{ Korean vocabulary } \\
\hline vowels & words & vowels & words \\
\hline /i/ & $\begin{array}{l}\text { ilu } \\
\text { (saliva) }\end{array}$ & / I/ ([i] ) & $\begin{array}{l}\text { 이름 [ir }[\mathrm{m}] \\
\text { (name) }\end{array}$ \\
\hline /e/ & $\begin{array}{l}\text { e'e } \\
\text { (water) }\end{array}$ & $\begin{array}{l}/-1 / / / H / \\
([\mathrm{e}])\end{array}$ & $\begin{array}{l}\text { 애완 } \\
\text { [ewan] } \\
\text { (pet) }\end{array}$ \\
\hline /a/ & $\begin{array}{l}\text { aka } \\
\text { (brother/ } \\
\text { sister) }\end{array}$ & $/$ - $\left(\left[\left[_{\ulcorner}\right]\right)\right.$ & $\begin{array}{l}\text { 으듬 }[\ulcorner\mathrm{t}\ulcorner\mathrm{m}] \\
\text { (basic) }\end{array}$ \\
\hline$/ \mathrm{u} /$ & $\begin{array}{l}\text { uka } \\
\text { (also) }\end{array}$ & $/ \dashv /([\ulcorner])$ & $\begin{array}{l}\text { 어른 [ }[\mathrm{r} \sqcap \mathrm{n}] \\
\text { (adult) }\end{array}$ \\
\hline \multirow[t]{3}{*}{ /o/ } & $\begin{array}{l}\text { Olu } \\
\text { (cloud) }\end{array}$ & $/$ / / ( [a] $)$ & $\begin{array}{l}\text { 아기 [agi] } \\
\text { (baby) }\end{array}$ \\
\hline & & $/ T /([\mathrm{u}])$ & $\begin{array}{l}\text { 우산 [usan] } \\
\text { (umbrella) }\end{array}$ \\
\hline & & /上/ ([o]) & $\begin{array}{l}\text { 오염 } \\
\text { [oy } ґ \mathrm{~m}] \\
\text { (pollution) }\end{array}$ \\
\hline
\end{tabular}

Table 2. Korean Informant Data

\begin{tabular}{|l|l|l|l|l|}
\hline No & Informant Code & Age & Gender & Origin \\
\hline 1 & fc1 & 19 & F & Sorawolio \\
\hline 2 & fc2 & 20 & F & Sorawolio \\
\hline 3 & fc3 & 30 & F & Sorawolio \\
\hline 4 & fc4 & 19 & F & Sorawolio \\
\hline 5 & fc5 & 21 & F & Sorawolio \\
\hline 6 & fc6 & 21 & F & Sorawolio \\
\hline 7 & fc7 & 20 & F & Sorawolio \\
\hline 8 & fc8 & 20 & F & Sorawolio \\
\hline 9 & fc9 & 20 & F & Sorawolio \\
\hline 10 & fc10 & 23 & F & Sorawolio \\
\hline 11 & mc1 & 19 & M & Sorawolio \\
\hline 12 & mc2 & 25 & M & Sorawolio \\
\hline 13 & mc3 & 26 & M & Sorawolio \\
\hline 14 & mc4 & 19 & M & Sorawolio \\
\hline 15 & mc5 & 24 & M & Sorawolio \\
\hline 16 & mc6 & 21 & M & Sorawolio \\
\hline 17 & mc7 & 20 & M & Sorawolio \\
\hline 18 & mc8 & 20 & M & Sorawolio \\
\hline 19 & mc9 & 24 & M & Sorawolio \\
\hline 20 & mc10 & Sorawolio \\
\hline
\end{tabular}

The informants were instructed to pronounce each word that had been selected twice (see Table 3) and record it with a Sony ICD-PX312 recording device. The distance between the recording device and the informant's mouth was approximately $10 \mathrm{~cm}$. In order to avoid the interference of the sound of expired air and thus affecting the quality of the recording it was specified that the recorder position had to be slightly below the informant's mouth. The recorder was also set to High Quality mode with a frequency of $44.100 \mathrm{~Hz}$.

After recording the informants, the audio data were stored on a computer with mp3 files, then grouped by informant and vowel type, then analyzed using the Praat4) program. To identify the characteristics of vowels, each vowel was analyzed with its first formant (F1) and second formant (F2). The process of analyzing the vowel formants began with opening the sound files in Praat and observing them using a spectogram. The formant measurement was done by determining the vowel parts with the cursors in the spectogram then pressing the automatic formant measurement feature namely, 'formant listing' feature in 'formant' menu. 
The measured formant value data were then normalized to eliminate gender, age, and other variables before commencing the statistical process. The vowel normalization process5) in this research used the Nearey 1 process provided in Norm6). According to Yun (2011) and $A h n(2014)$, there are many methods that can be used for the vowel normalization process. Nevertheless, the normalization method using the Nearey process is the most effective method for normalizing vowels hence was used for this research. The data that had gone through the normalization process was used to analyze the differences in the vocal characteristics of the two languages

The differences between Korean and Cia-Cia may cause problems in transcribing Cia-Cia with Hangeul. Therefore, this research also analyzes the implementation of vowel transcription of the Cia-Cia language into Hangeul including the problems that arise in transcribing Cia-Cia vowels into Hangeul caused by the differences between the two languages.

\section{FINDINGS AND DISCUSSION}

\section{Differences in Cia-Cia and Korean Vowel Systems}

The classification of Korean and Cia-Cia vowels presented in Table 4 below can be classified based on the tongue height, the tongue position and the lip shape. The vowels grouped into high, middle, and low vowels based on the tongue height and tongue position can be divided into front and back vowels. Then, if classified according to the lip shape, in general, it can be divided into rounded and unrounded vowels.

There are several studies comparing Cia-Cia and Korean phonemes. In general, the discussion section of Cia-Cia language below refers to Mustafa Abdullah (1991). According to Taehyun Jeon, Hoyoung Lee (2009), Taehyun Jeon (2010), Bokyung Kim (2012), and Dessiar (2020), the Cia-Cia single vowels are / a /, / i /, / o /, / u /, and $/ \mathrm{e} /$. Based on the tongue height, the vowel $/ \mathrm{i} /$ and $/ \mathrm{u} /$ are high vowels, the vowel /e/ and /o/ are middle vowels, and the vowel /a/ is a low vowel. Based on the tongue position, the vowel /i/ and /e/ belong to front vowels while the vowel $/ \mathrm{u} /, / \mathrm{o} /$ and $/ \mathrm{a} /$ belong to back vowels. Additionally, Cia-Cia single vowels are much simpler, and their number less than Korean single vowels.

There are many different opinions on the classification of Korean vowels. In terms of the number of single vowels, based on the work of linguistic scientists, they can be divided into seven vowels, eight vowels to ten vowels. The highest number of vowels is ten vowels and are as follows: "/ / / ([i] $]), /$ / / ([e] $), / H /([\varepsilon]), /$ / ([a] $)$,

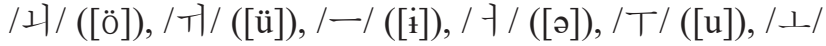
([o])'. However, most scientists including Bae (1996) and Sin (2003), agree that the vowel / 기/ ([0̈]) and / T/ / ([ü]) in medieval Korean were classified as single vowels but in modern Korean they are pronounced as double vowel /기/ ([we]) and / Tㄱ/ ([wi]). Subsequently, according to Sin (2003), the vowel / 기 / and / H / whose pronunciations used to be divided into $[\mathrm{e}]$ and $[\varepsilon]$ is now pronounced the same, namely [e]. This is despite the writing of the vowel still having two forms. Consequently, most Korean linguistic scientists classify Korean single vowels into seven vowels, namely / / / ([i] ), / 기 / ([e]), / F / ([a] ), /一/ ([i] $]), / \dashv /([ə]), / 丁 /([u]), / \perp /([o])$ '. Similarly, in this research, the Korean vowels used as the research objects are these seven vowels.

Of these seven Korean vowels based on the vowel height, the vowel "/ / / ([i] ), / / ([i] ]) and / T/ ([u] belong to high vowels, the vowel / H/ / ([e]), / † / ([ə]]) and / L/ ([o]) belong to middle vowels and the vowel/ / / ([a]) belong to low vowels. Based on the tongue position, the vowel / / / ([i]) and / ㄱ / ([e]) belong to front vowels and the rest (/一/ ([i] $), / T /([\mathrm{u}]), / 才 /([a]), / \perp /([\mathrm{o}]), /$ / ([a])) belong to back vowels. The following is a table comparing Cia-Cia and Korean vowels.

Table 4. Comparison of Cia-Cia and Korean Vowels

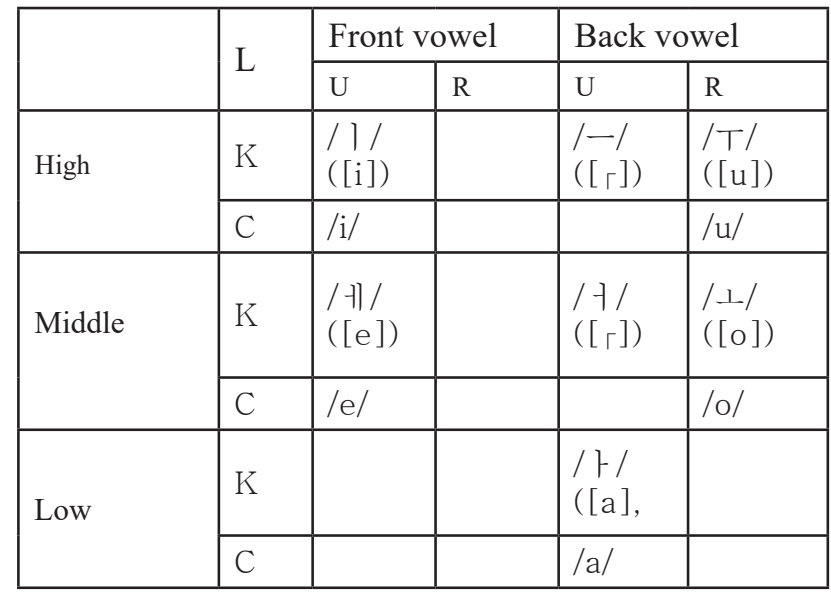

$\mathrm{L}=$ Language, $\mathrm{U}=$ unrounded, $\mathrm{R}=$ rounded, $\mathrm{K}=$ Korean, $\mathrm{C}=$ Cia-Cia

As show in Table 4 there are several vowels that have the same classification and can be equivalent to each other such as the Cia-Cia vowel /i/, can be equivalent to the Korean vowel /이/ ([i]), the vowel/e/, to the vowel /에/ ([e]), the vowel/a/ to the vowel/아/ ([a]), the vowel $/ \mathrm{u} /$, to the vowel / 우/ ([u]), and the vowel /o/ to the vowel /오/ ([o]). Furthermore, there are two Korean vowels that have no Cia-Cia equivalent namely the vowel /으/ ([i] ) 
and the vowel /어/ ([ə]), since no single Cia-Cia vowel sounds like those two vowels.

\section{Comparison of Acoustic Characteristic of Cia-Cia and Korean Vowels}

In this section the acoustic characteristic of Cia-Cia and Korean vowels are compared. Before comparing the vowels of the two languages, the vowel formant (F1 and F2) values from the two languages are analyzed. As mentioned above, the vowel formant position is very much influenced by a number of variables such as the anatomy and physiology of each speaker, so even though they pronounce the same vowel, the frequency value can vary. Therefore, to eliminate any non-verbal variations that might occur among speakers, vowel normalization was carried out using the Nearey process. Additionally, the results were tested statistically with the T-test. The following are the vowel formant values before and after normalization.

Figures 1 and 2 are the results before and after the vowel normalization of Korean speakers. Figures 3 and 4 are the results before and after the vowel normalization of Cia-Cia speakers. It can be seen from the figures that
Figure 1. Korean vowel formant values (Non-normalized)

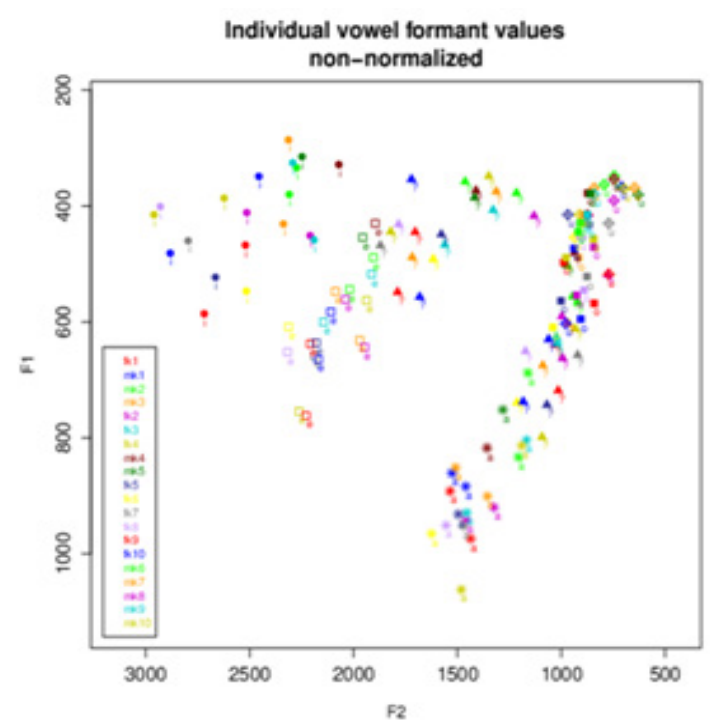

Figure 2.Korean vowel formant values (Nearey normalized)

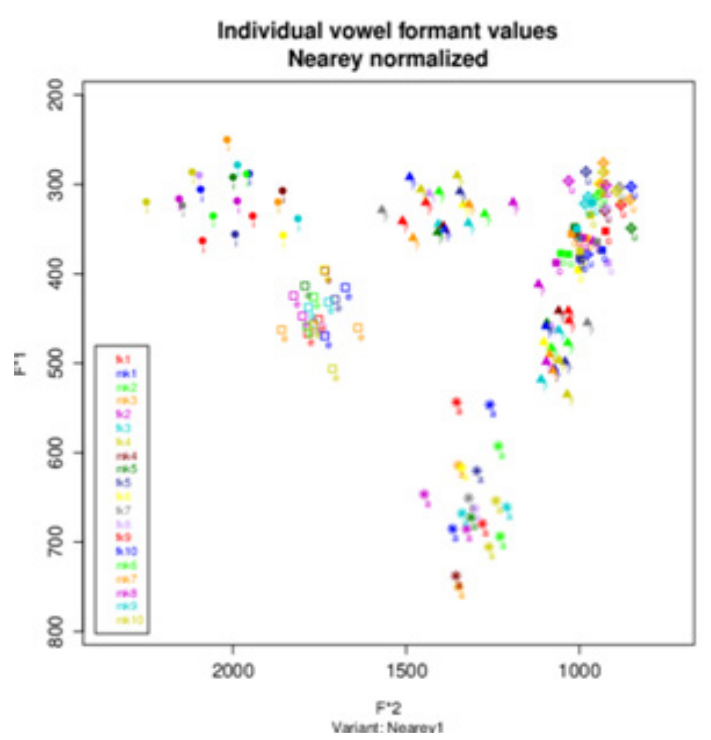

Figure 3. Cia-cia vowel formant values (Non-normalized)

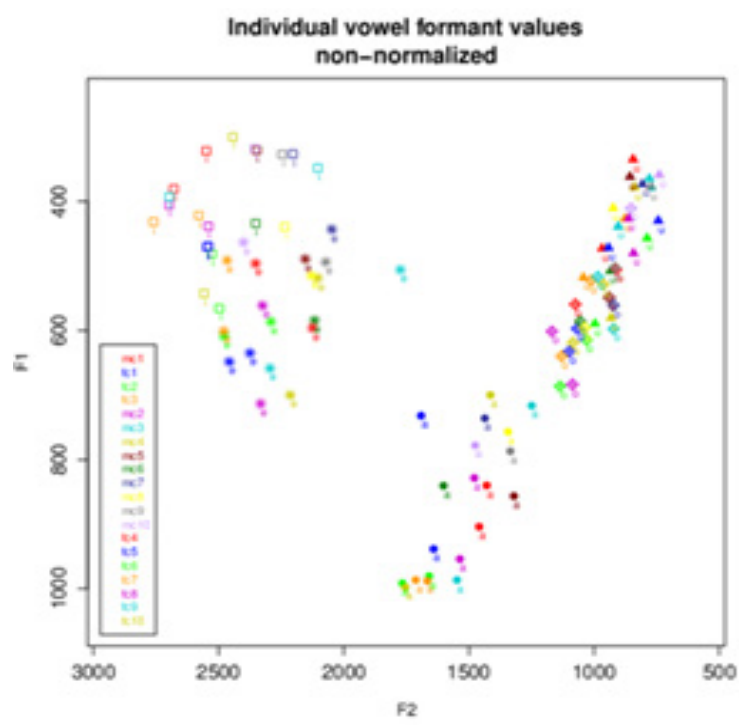

Figure 4. Cia-cia vowel formant values (Nearey normalized)

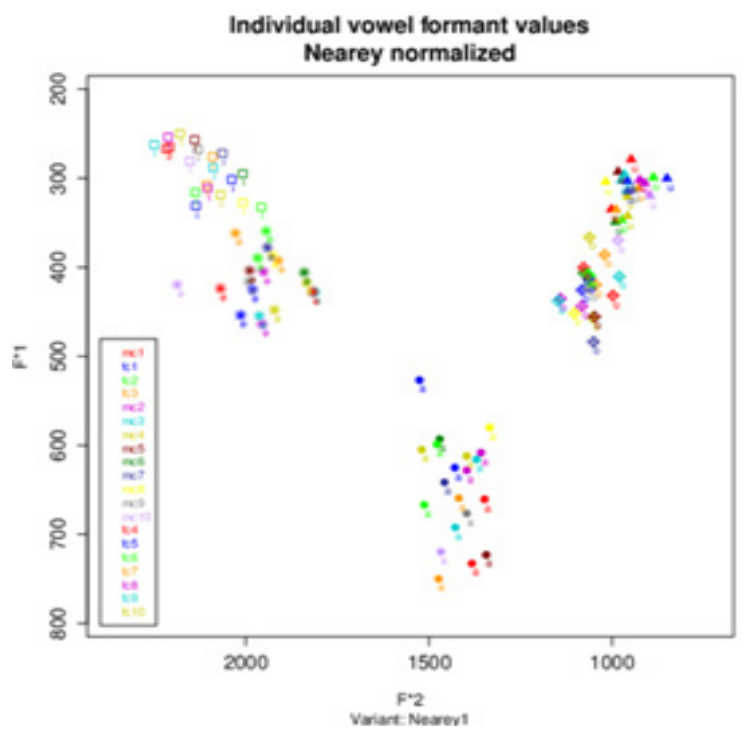


are before the normalization process, the vowel position taken from several informants is separated from the average vowel position of other informants. The figure on the bottom is after the normalization process is applied where the vowels look more centered.

In collating the data used in this research a check was made to ensure there were no data from informants whose pronunciation was very different from the average of other informants. An inclusion of such data could affect the overall analysis results. Accordingly, the next process was to conduct a T-test to verify whether there was a significant difference between the vowels pronounced in one informant group. The results were that all $\mathrm{P}$ values were higher than 0.05 ( $\mathrm{P}$ value of the Korean informant $\mathrm{F} 1=0.854, \mathrm{P}$ value of the Korean informant F2 $=0.982, \mathrm{P}$ value of the Indonesian informant $F 1=0.937$, and $P$ value of the Indonesian informant $\mathrm{F} 2=0.973$ ). In the T-test, if $\mathrm{P}$ value is higher than 0.05 , then it can be concluded that there were no significant differences in the data. As a result, the results of bilingual vowel formant analysis that had gone through the normalization process could be used in this research.

\section{Acoustic Characteristics of Cia-Cia vowels}

The following are the findings from the analysis of the Cia-Cia vowel formant pronounced by Cia-Cia speakers. The displayed vowel formant values are the average F1 and F2 values that have been normalized using the Nearey1 method.

Table 5. F1 and F2 values for Cia-Cia Vowels

\begin{tabular}{|l|l|l|l|l|l|}
\hline & i & e & a & u & o \\
\hline F1(Hz) & 288 & 413 & 645 & 313 & 421 \\
\hline F2(Hz) & 2114 & 1951 & 1425 & 950 & 1059 \\
\hline
\end{tabular}

From the analysis of the formant values (F1 and F2), the characteristics of Cia-Cia vowels from the tongue height and tongue position when Cia-Cia speakers pronounced vowels can be seen. The F1 values were related to the tongue height or oral cavity opening size when pronouncing the vowel. The higher the F1 values, the higher the tongue position or the larger the oral cavity opening when pronouncing the vowel (Sin 2014: 193). The analysis results showed that the order of the $\mathrm{F} 1$ values from the highest was $/ \mathrm{a} />/ \mathrm{o} />/ \mathrm{e} />/ \mathrm{u} />/ \mathrm{i} /$.

In contrast, the $\mathrm{F} 2$ values were related to the tongue position (front or back) when pronouncing the vowel. The further back the tongue was when pronouncing a vowel, the smaller the F2 values (Sin 2014: 193). The analysis
Figure 5. Cia-Cia vowel position

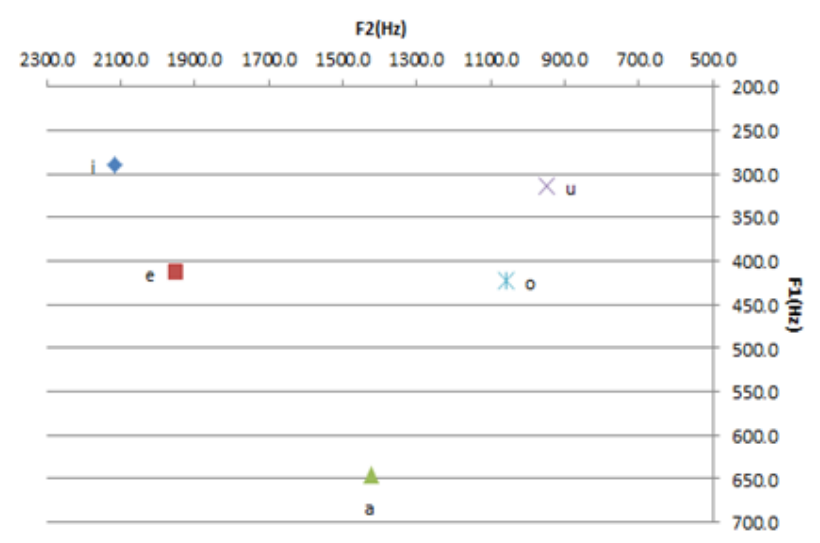

shows that the order of the F2 values from the highest was $/ \mathrm{i} />/ \mathrm{e} />/ \mathrm{a} />/ \mathrm{o} />/ \mathrm{u} /$. Figure 5 is the position map of Cia-Cia vowels made based on Table 5 .

As can be seen in Figure 5, the Cia-Cia vowels /i/ and /e/ have quite large F2 values compared to other vowels whereas the vowels /u/, /o/, /a/ have smaller F2 values. From these results, it can be concluded that based on the tongue position (front and back), the vowel /i/ along with the vowel /e/ belong to the front vowels, while the vowel / $\mathrm{u} /$ along with the vowels $/ \mathrm{o} /$ and /a/ belong to back vowels. The vowel /a/ had the highest $\mathrm{F} 1$ value compared to other vowels, so the vowel /a/ based on the tongue height belong to the low vowel. In contrast, the vowels $/ \mathrm{i} /$ and $/ \mathrm{u} / \mathrm{had}$ very low $\mathrm{F} 1$ values, so they belong to high vowels, the vowels /e/ and /o/ belong to middle vowels since the $\mathrm{F} 1$ values were classified as moderate.

\section{Acoustic Characteristics of Korean vowels}

The following is the analysis of Korean vowel formant pronounced by Korean speakers. The displayed vowel formant values are the average $\mathrm{F} 1$ and $\mathrm{F} 2$ values that have been normalized using the Nearey 1 method.

Table 6. F1 and F2 values for Korean vowels

\begin{tabular}{|l|l|l|l|l|l|l|l|}
\hline & $\begin{array}{l}\text { 이 } \\
{[\mathrm{i}]}\end{array}$ & $\begin{array}{l}\text { 에 } \\
{[\mathrm{e}]}\end{array}$ & $\begin{array}{l}\text { 아 } \\
{[\mathrm{a}]}\end{array}$ & $\begin{array}{l}\text { 으 } \\
{[\mathrm{i}]}\end{array}$ & $\begin{array}{l}\text { 어 } \\
{[\mathrm{j}]}\end{array}$ & $\begin{array}{l}\text { 우 } \\
{[\mathrm{u}]}\end{array}$ & $\begin{array}{l}\text { 오 } \\
{[\mathrm{o}]}\end{array}$ \\
\hline $\begin{array}{l}\mathrm{F} 1 \\
(\mathrm{~Hz})\end{array}$ & 313 & 443 & 654 & 328 & 476 & 311 & 364 \\
\hline $\begin{array}{l}\mathrm{F} 2 \\
(\mathrm{~Hz})\end{array}$ & 2011 & 1754 & 1308 & 1373 & 1066 & 927 & 991 \\
\hline
\end{tabular}

The number of Korean vowels then is more than the number of Cia-Cia vowels. The analysis shows that 
Figure 6. Korean vowel position

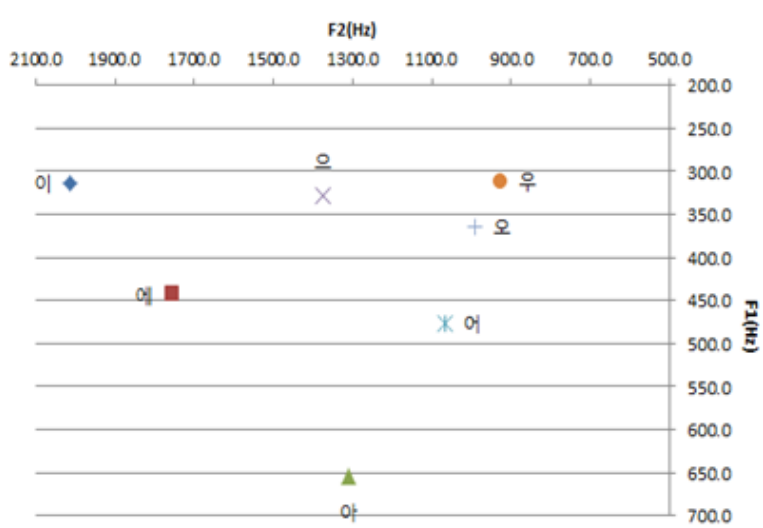

the F1 values of the highest value were /아/ $>/$ 어/ $>$ /에/ > / ㄴ/ > /으/ > / 이/ > / 우/ and the F2 values of the highest value were /이/ > /에/ > /으/ > /아/ > /어/ > /오/ $>/$ 우/. Figure 6 is the position map of Korean vowels made based on Table 6 .

As can be seen in Figure 6, the vowels / 이/ ([i]) and /에/ ([e]) have the highest F2 values compared to other vowels, so based on the tongue position these two vowels belong to the front vowels. In addition, the vowel /우/ ([u]) along with the vowel/오/, /어/, /으/ and /아/ belonged to the back vowels. On the other hand, the vowel /아/ ([a]) had the highest F1 value compared to other vowels, so based on the tongue height the vowel /아/ ([a]) belonged to the low vowels. Additionally, the vowels /이/, /으/ and /우/ had very low F1 values, so they belonged to high vowels, while the vowels /에//어/ and / 오/ belonged to middle vowels since their F1 values were moderate.

\section{Comparison of Cia-Cia and Korean Vowels}

The comparison of Cia-Cia and Korean vowel formant values can be seen in Figure 7 below. When compared the single vowels of those two languages shows similarities and differences (see Figure 7 below). There are Korean vowels that could not be equated to Cia-Cia vowels, but there are also those that could be equated based on the classification. The Cia-Cia vowel /i/ is equivalent to the Korean vowel /이/ ([i] ), the vowel/e/ to /에/ ([e]), the vowel /a/ to /아/ ([a]), the vowel/u/ to the vowel/우/ ([u]), and the vowel/o/ to /오/ ([o]). Additionally, there are two Korean vowels that have no Cia-Cia equivalents, namely the vowel /으/ ([i]]) and the vowel /어/ ([ə]) that is, there is no single Cia-Cia vowel sounding like those two vowels.
Figure 7. Comparison of Cia-Cia and Korean vowels

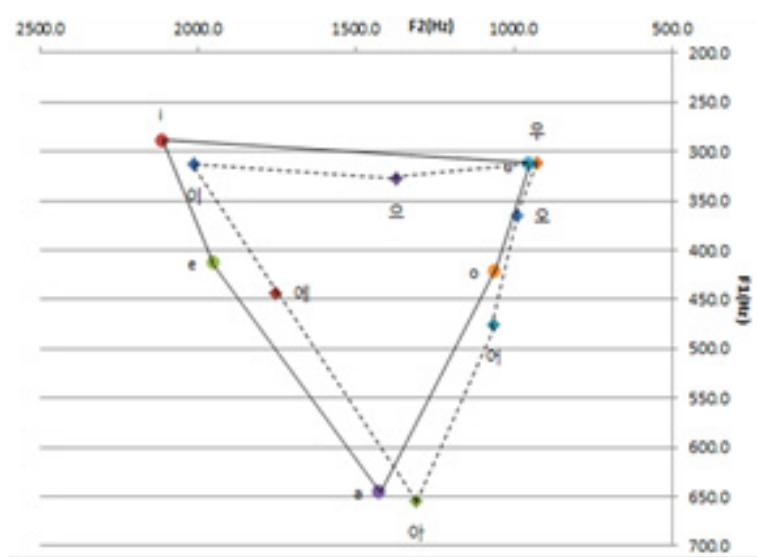

As shown in Figure 7, visually there are two vowels that belong to one classification whose positions appear close together, but there are also those slightly apart compared to other vowels. For example, the position of the Korean vowel / T/ ([u]) and the Cia-Cia vowel /u/ looked very close, compared to other equivalent vowels. The following are the T-test results to detect whether there is a difference between equivalent Cia-Cia and Korean vowels.

Table 8. T-test results of Cia-Cia and Korean single vowels with equal classifications

\begin{tabular}{|c|c|c|c|c|}
\hline \multicolumn{2}{|c|}{ Comparison } & \multirow{2}{*}{$\begin{array}{l}\text { Korea } \\
313\end{array}$} & \multirow{2}{*}{$\begin{array}{l}\text { Cia-Cia } \\
288\end{array}$} & \multirow{2}{*}{$\begin{array}{l}\text { P value } \\
\mathrm{p}=.009 \\
(\mathrm{t}=2.712)\end{array}$} \\
\hline /i/ and & $\begin{array}{l}\text { F1 } \\
(\mathrm{Hz})\end{array}$ & & & \\
\hline /이/ ([i]) & $\begin{array}{l}\mathrm{F} 2 \\
(\mathrm{~Hz})\end{array}$ & 2011 & 2114 & $\begin{array}{l}\mathrm{p}=.001 \\
(\mathrm{t}=-3.322)\end{array}$ \\
\hline \multirow{2}{*}{$\begin{array}{l}\text { /e/ and } \\
\text { /에/ ([e]) }\end{array}$} & $\begin{array}{l}\text { F1 } \\
(\mathrm{Hz})\end{array}$ & 443 & 413 & $\begin{array}{l}\mathrm{p}=.001 \\
(\mathrm{t}=3.365)\end{array}$ \\
\hline & $\begin{array}{l}\mathrm{F} 2 \\
(\mathrm{~Hz})\end{array}$ & 1754 & 1951 & $\begin{array}{l}\mathrm{p}=.000 \\
(\mathrm{t}=-8.641)\end{array}$ \\
\hline \multirow{2}{*}{$\begin{array}{l}\text { /a/ and } \\
\text { /아/ ([a]) }\end{array}$} & $\begin{array}{l}\text { F1 } \\
(\mathrm{Hz})\end{array}$ & 654 & 645 & $\begin{array}{l}\mathrm{p}=.630 \\
(\mathrm{t}=.485)\end{array}$ \\
\hline & $\begin{array}{l}\mathrm{F} 2 \\
(\mathrm{~Hz})\end{array}$ & 1308 & 1425 & $\begin{array}{l}\mathrm{p}=.000 \\
(\mathrm{t}=-6.224)\end{array}$ \\
\hline \multirow{2}{*}{$\begin{array}{l}/ \mathrm{u} / \text { and } \\
/ \text { 우/ ([u]) }\end{array}$} & $\begin{array}{l}\text { F1 } \\
(\mathrm{Hz})\end{array}$ & 311 & 313 & $\begin{array}{l}\mathrm{p}=.786 \\
(\mathrm{t}=-.273)\end{array}$ \\
\hline & $\begin{array}{l}\mathrm{F} 2 \\
(\mathrm{~Hz})\end{array}$ & 927 & 950 & $\begin{array}{l}\mathrm{p}=.116 \\
(\mathrm{t}=-1.607)\end{array}$ \\
\hline \multirow{2}{*}{$\begin{array}{l}\text { /o/ and } \\
\text { /오/ ([o]) }\end{array}$} & $\begin{array}{l}\mathrm{F} 1 \\
(\mathrm{~Hz})\end{array}$ & 364 & 421 & $\begin{array}{l}\mathrm{p}=.000 \\
(\mathrm{t}=-7.262)\end{array}$ \\
\hline & $\begin{array}{l}\mathrm{F} 2 \\
(\mathrm{~Hz})\end{array}$ & 991 & 1059 & $\begin{array}{l}\mathrm{p}=.000 \\
(\mathrm{t}=-5.152)\end{array}$ \\
\hline
\end{tabular}


Table 8 shows the T-test results for equivalent Cia-Cia and Korean vowels. Those in F1 and F2 for the Cia-Cia vowel /u/ and the Korean vowel / 우/ ([u]) both had $\mathrm{P}$ values higher than 0.05 , so it could be said that there was no significant difference in the tongue position and tongue height when pronouncing the vowel. In other words, the two vowels belonged to the same classification, which is the high back vowels. From the results of experimental phonetic analysis, the two vowels also have the same acoustic characteristics. F1 values were related to the tongue height or oral cavity opening size when pronouncing the vowel. The greater the F1 value, the greater the oral cavity opening when pronouncing the vowel. It could be said that when Korean speakers pronounced the vowel /우/ ([u]) and Cia-Cia speakers pronounced the vowel /u/, the oral cavity opening levels were the same. On the other hand, F2 values were related to the tongue position when pronouncing the vowel. It can be said that when Korean speakers pronounced the vowel / 우/ ([u]) and Cia-Cia speakers pronounced the vowel $/ \mathrm{u} /$, the tongue positions were the same.

Second, based on the T-test results of the Cia-Cia vowel /a/ and the Korean vowel /아/ ([a]), the P value of F1 was the only one that showed no significant difference. As a result, it could be said that the oral cavity opening levels were the same. Nonetheless, there was a difference in the tongue position when pronouncing the vowel.

Third, for other vowels, the T-test results of F1 and $\mathrm{F} 2$ revealed that all $\mathrm{P}$ values were less than 0.05 , so it could be said that there was a significant difference in both tongue position and oral cavity opening level when pronouncing the vowels. Both the Cia-Cia vowel /i/ and the Korean vowel/이/ ([i]) were high vowels, the oral cavity opening level when pronouncing the Cia-Cia vowel /i/ was lower than the Korean vowel / 이/ ([i]). Although both of them were front vowels, the tongue position when pronouncing the Cia-Cia vowel /i/ was further forward than when pronouncing the Korean vowel /이/ ([i] $)$.

Fourth, based on the tongue height, both the Cia-Cia vowel/e/ and the Korean vowel/에/ / [e]) were middle vowels, but the oral cavity opening level when pronouncing the Cia-Cia vowel was smaller than that of the Korean vowel /에/ ([e]). Although both of them were front vowels, the tongue position when pronouncing the Cia-Cia vowel was further forward than when pronouncing the Korean vowel /에/ ([e]).

Fifth, based on the tongue height, both the CiaCia vowel /o/ and the Korean vowel / 오/ ([o]) were middle vowels, but the oral cavity opening level when pronouncing the Cia-Cia vowel /o/ ([o]) was higher than the Korean vowel /오/ ([o]). Although both of them were back vowels, the tongue position when pronouncing the Cia-Cia vowel /o/ was further forward than when pronouncing the Korean vowel/오/ ([o]).

\section{Implementation of Vowel Transcription of Cia-Cia Language into Hangeul}

The previous section discusses the differences in vowels in the Cia-Cia language and in Korean. This section discusses the vowel writing system in Korean adopted for the Cia-Cia language and investigates associated vowel transcription problems.

In Korean, vowels can stand alone and form one syllable, but according to its writing system, the vowel in Korean must be accompanied with consonants in front of it. Therefore, a vowel at the beginning of syllable always follows the consonant ' $O$ ' (iung), which is muted when it is used at the beginning of syllable. Figure 8 presents examples of writing vowels at the beginning of a syllable.

The rules of vowel transcription in the Cia-Cia language are implemented using the vowel writing rules in Korean (Hangeul). Therefore, in the Cia-Cia language, the vowel transcription written at the beginning of syllable also adopts the Korean writing system which must write the consonant ' $O$ ' before the vowel. Table 9 shows examples of vowel transcriptions in the Cia-Cia language based on its position.

As discussed in the previous section, all vowels in Cia-Cia can be transcribed into Korean. Vowel / i / in Cia-Cia is equivalent to / 이/([i]) in Korean, vowel /e/ to /에/ ([e]), vowel / a / to /아/ ([a]), vowel /u/ to /우/ ([u]), and lastly, vowel /o/ to / 오/ ([o]). Therefore, for vowel transcription of the Cia-Cia language, it can be transcribed into these equivalent vowels. Table 10 shows vowel transcription of Cia-Cia language into Hangeul.

The table 10 shows that in general, in terms of vowel equivalents, there is no problem in transcribing Cia-Cia vowels into Korean Hangeul. However, looking at Cia-Cia vowel transcription, there is one vowel '-

Figure 8. Vowel writing at beginning of a syllable

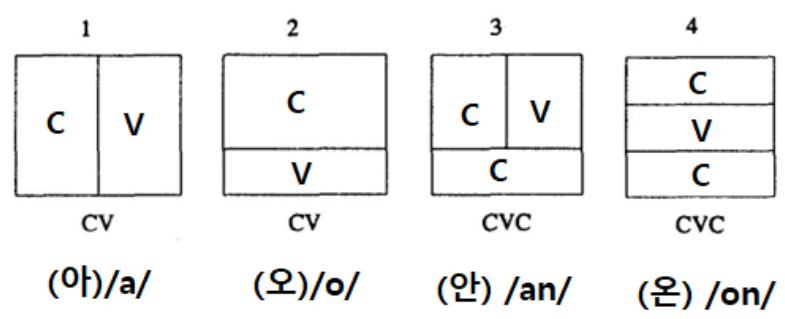


Table 9. Vowel distribution in Cia-Cia language and transcription in Hangeul

\begin{tabular}{|c|c|c|c|}
\hline vowel & $\begin{array}{l}\text { Beginning of } \\
\text { syllable }\end{array}$ & $\begin{array}{l}\text { Middle of } \\
\text { syllable }\end{array}$ & End of syllable \\
\hline$/ \mathrm{a} /$ & $\begin{array}{l}\text { /ama/ } \\
\text { (아마) } \\
\text { father }\end{array}$ & $\begin{array}{l}\text { /cindala/ ( } \\
\text { 찐달라) } \\
\text { ask }\end{array}$ & $\begin{array}{l}\text { /amea/ (아메 } \\
\text { 아) } \\
\text { one }\end{array}$ \\
\hline /i/ & $\begin{array}{l}\text { /isa/ } \\
\text { (이사) } \\
\text { fish }\end{array}$ & $\begin{array}{l}/ \mathrm{mia} / \text { (미 } \\
\text { 아) } \\
\text { people }\end{array}$ & $\begin{array}{l}\text { /nanasi/ (나나 } \\
\text { 시) } \\
\text { pineapple }\end{array}$ \\
\hline$/ \mathrm{u} /$ & $\begin{array}{l}\text { /uka/ } \\
\text { (우까) } \\
\text { also }\end{array}$ & $\begin{array}{l}/ \mathrm{mbule} / \text { ( } \\
\text { 음불레) } \\
\text { (go home) }\end{array}$ & $\begin{array}{l}\text { /6icu/ (피쭈) } \\
\text { love }\end{array}$ \\
\hline /e/ & $\begin{array}{l}\text { lesi/ } \\
\text { (에시) } \\
\text { ice }\end{array}$ & $\begin{array}{l}\text { /wea/ } \\
\text { (봉 게아) } \\
\text { attic }\end{array}$ & $\begin{array}{l}\text { /pilinge/ (삘 링 } \\
\text { 에) } \\
\text { middle }\end{array}$ \\
\hline /o/ & $\begin{array}{l}\text { /olu/ [올루] } \\
\text { cloud }\end{array}$ & $\begin{array}{l}\text { /sopu/ [소 } \\
\text { 뿌] } \\
\text { hug }\end{array}$ & $\begin{array}{l}\text { /ilio/ [일리오] } \\
\text { peep }\end{array}$ \\
\hline
\end{tabular}

Table 10. Vowel transcription of Cia-cia language into Hangeul

\begin{tabular}{|l|l|l|l|l|l|l|}
\hline Cia-Cia Vowel & {$[\mathrm{a}]$} & {$[\mathrm{e}]$} & {$[\mathrm{i}]$} & {$[\mathrm{o}]$} & {$[\mathrm{u}]$} & \\
\hline $\begin{array}{l}\text { Hangeul } \\
\text { Transcription }\end{array}$ & $\vdash$ & $\dashv$ & $\mathrm{I}$ & $\perp$ & $\top$ & - \\
\hline
\end{tabular}

Table 11. Example of double consonants

\begin{tabular}{|c|c|c|}
\hline No & Cia-cia Language & Transcription \\
\hline 1 & $\begin{array}{l}\text { /mbu-le/ } \\
\text { (go home) }\end{array}$ & $\begin{array}{l}\text { 음불레 [「m-bul- } \\
\text { le }]\end{array}$ \\
\hline 2 & $\begin{array}{l}\text { / pko- го/ } \\
\text { (squat) }\end{array}$ & $\begin{array}{l}\text { 은고오 } \quad\left[\left\ulcorner\mathrm{n}-\mathrm{kO}^{-}\right.\right. \\
\text {ГO }]\end{array}$ \\
\hline 3 & $\begin{array}{l}\text { /ndo-ke/ } \\
\text { (monkey) }\end{array}$ & $\begin{array}{l}\text { 은도께 } \quad\left[\left\ulcorner\mathrm{n}-\mathrm{do}^{-}\right.\right. \\
\mathrm{ke}]\end{array}$ \\
\hline
\end{tabular}

in Korean, which is not found in Cia-Cia, but it is still used in vowel transcription of the Cia-Cia language. The use of the Korean vowel '- ' in the Cia-Cia language transcription is not related to the characteristics of the vowel in Cia-Cia. There is no vowel in Cia-Cia which has the same sound as the vowel '-' ([i]). The use of vowel ' - ' is closer to the modern Korean writing system in expressing double consonants at the beginning of a syllable. Even though the modern Korean writing system has no such double consonants at the beginning of syllable, double consonants are nevertheless frequently used to write loan words from other languages.
In Korean, consonant must be followed with a combination of vowels. Accordingly, double consonants must be added with the vowel '-' ([i]) in between or at the front of the consonants. When writing the double consonants of loan word from English, for example 'stress', then the vowel '-' ([i]) must be inserted in between the consonants, so it becomes '스트레스' and read [sitiresi].

The use of vowel '-' ([i]) is a unique feature of the Korean language that has no relationship with Cia$\mathrm{Cia}$ language. Hence, the question that arises is whetherto implement the use of the vowel '-' ([i]) to write double consonants in Cia-Cia language. The main problem is the rule for writing double consonants in Cia-Cia transcription into Hangeul. Korean has a phonological characteristic where the number of consonants that may appear at the beginning of syllable is limited to one, or in other words, it is not permissible to have double consonants at the beginning of a syllable. Whereas in the Cia-Cia language, the use of double consonants such as /mb, nd, mp, nt, nc/ at the beginning of a syllable is a unique characteristic, which is attached and inseparable. With the differences in the unique features or phonological characteristics between the two languages, problems in transcribing Cia-Cia language into Hangeul may occur as illustrated in Table 11.

Table 11 shows that the rule for writing a double consonant transcription in Cia-Cia language follows exactly the same writing system in Korea. the examples in numbers 1, 2 and 3 in Table 11 show Cia-Cia words /mbu-le/, / pko-?o/, /ndo-ke/, which consist of two syllables $/ \mathrm{mbu} / \mathrm{and} / \mathrm{le} /, / \mathrm{jko} /$ and $/ \mathrm{ro} /$, then $/ \mathrm{ndo} / \mathrm{and}$ $/ \mathrm{ke} /$. Double consonants exist at the beginning of the syllable. As explained earlier, the number of consonants at the beginning of a syllable in Korean is only one, so in its transcription process, the double consonants is divided into two different syllables. Given that in the Korean writing system a consonant cannot stand alone in one syllable and must be followed with a combination of vowels, then the vowel ' - ' is added at the front of consonant $/ \mathrm{m} /, / \mathrm{y} /$ and $/ \mathrm{n} /$ as shown in the example of words in Table 11 above.

This transcription process of the Cia-Cia language results in syllables being different to their original form. This effect causes linguistic problems because if the syllable form changes, then the pronunciation will be changed. In examples 1, 2 and 3 in Table 11, the word / mbule/ is transcribed as [im-bul-le], and /nko?o/ as [inko-?o], then /ndoke/ as [in-do-ke]. There are changes in the number of syllables, where the source language has two syllables it changes to three syllables after the 
transcription process. Furthermore, the structure of the first syllable which was CCV, now becomes CV after the transcription process. In addition, some changes in phonemes are found due to the transcription process.

\section{CONCLUSION}

This research analyzed the acoustic phonetic characteristics of Cia-Cia and Korean single vowels, and found differences and similarities between them. Based on the classification according to the tongue position and tongue height, the Cia-Cia vowel /i/ is equivalent to the Korean vowel /이/ ([i]), the vowel/e/ to the vowel/에/ ([e]), the vowel /a/ to the vowel/아/ ([a]), the vowel /u/ to the vowel /우/ $([\mathrm{u}])$, and the vowel /o/ to the vowel /오/ ([o]). Additionally, there are two Korean vowels that have no Cia-Cia equivalent, namely /으/ ([i]) and /어/ ([ə]), with no single Cia-Cia vowel sounding like these two vowels.

Consequently, although the vowel equivalents of those two languages have the same classification, in general each vowel has different phonetic characteristics. Nevertheless, unlike other vowel equivalents, the Cia-Cia vowel/u/ and the Korean vowel / 우/ ([u]) show that they have the same phonetic characteristics in terms of tongue position and height when pronounced. The Cia-Cia vowel /a/ and the Korean vowel /아/ ([a]), meanwhile, show that when pronounced they have the same tongue height, but different tongue position.

Although in Cia-Cia there isas no vowel equivalent to the Korean vowel / 으/ ([i] ), the use of the vowel/으/ ([i]) can be seen in the Korean letter (Hangeul) transcription in Cia-Cia. The use of the vowel /으/ ([i]) in Hangeul writing in $\mathrm{Cia}-\mathrm{Cia}$ is unrelated to the characteristics of Cia-Cia vowels. This is a consequence of the limitations of Korean syllables that do not use double consonants. In Korean, between two double consonants, according to the rule, the vowel /으/ ([i] ) needs to be inserted. However, the application of this rule is inappropriate for Cia-Cia writing, considering that it does not have the vowel /으/ ([i]). This causes linguistic problems because this transcription process from the Cia-Cia language results in different syllables from their original form.

If this problem is not given serious attention, it could become a new issue in efforts to preserve the CiaCia language. The Cia-Cia language preservation program, which is based on transcribing it into Hangeul, aims to preserve the endangered Cia-Cia language. However, in the transcription process, the unique linguistic features or characteristics of the source language must be taken into account, not just the characteristics related to equivalent phonemes. These unique linguistic features are related to phoneme distribution and limitations in using phonemes at the syllable level. If these issues are not considered in detail, the Cia-Cia language preservation program could erode the unique characteristics of the language itself.

\section{ENDNOTES}

1) https://www.bps.go.id/news/2015/11/18/127/mengulikdata-suku-di-indonesia.html

2) (Summer Institute of Linguistics, SIL) http://www. ethnologue.com/show_language.asp?code=cia).

3 ) In the 16th century various types of modified Arabic letters were used to translate the Quran. On Buton Island, there are many ancient manuscripts from the Islamic kingdom of Buton in the Wolio language written in Buri Wolio letters which were modified Arabic letters similar to Jawi letters, but have slight differences in the number and types of letters (Yamaguchi 2007: 46).

4) Praat is a software that can be used in acoustic analysis which consists of two activities, which are speech segmentation and speech synthesis. More details about Praat can be found at https://prat.org/

5) Yun (2011) argues that vocal formants are greatly influenced by anatomy and physiology such as the shape of the speaker's pronunciation organs, gender, age, and other related factors. Therefore, even though the vowels are pronounced the same, there can be differences in their frequency. To anticipate the differences that can arise from each of the same speech groups, a vocal normalization process is needed

6) Norm is a web-based normalization tool developed by Thomas, Erik R, and Tyler Kendall (2007). The Nearey vowel normalization is known to be useful in closing the possibility of differences influenced by physiological differences while maintaining sociolinguistic variations. More information about the Norm and Nearey vowel normalization can be found at http://lingtools.uoregon. edu/norm/norm1_help.php.

\section{REFERENCES}

Ahn, M. A. (2014). An Experimental Study of Korean Simple Vowel Acquisition of Indonesian Advanced Learners. Journal of the Language and Culture. 10(1). 177-205

Bae, J. C. (1996). Introduction of Korean Phonology. Seoul: Singumunwahsa Press.

Cho, T. H. (2012). Cia-Cia Language: From The Era Of Oral To The Era Of Writing. Humaniora, 24(3), 324.-332.

Chun, T. H. (2010), Language Policy in Indonesia: Relating to the Issue of Cia-Cia Tribe's Adoption of the Korean Alphabet as Its Writing System. Journal of 
the International Network for Korean Language and Culture. 7(2). 171.-193.

Chun, T. H \& Cho, T. Y. (2012), The Future of Hangeulbased Cia-Cia Script: A Perspective of the History of Writing System. Journal of Hangeul. 289(1). 107.136.

Chun, T. H \& Lee, H. Y. (2009). Indonesian Minority Language Studies: Cia-Cia. Journal of The Linguistic Society of Korea, 6(1). 7-16.

Dessiar, A. R. (2020). A Study on the Correlation between the Transcription of Cia-Cia Language into Hangeul and the Cia-Cia Language Characteristics. Journal of Institute For The Humanities, 78(1), 5.-34. . (2021). Contrastive Study on Cia-Cia and Korean Consonants-Based on Typological Universals. Journal of the Korean Language and Literature Education. 76(1). 137-170.

Jang. H. J. (2006). An Acoustic Study on the Generational Difference of the Monophthongs in the Daegu Dialect. Seoul: Korea University Press.

Kim, B. G. (2012). A Case study on internationalization of Hangeul. In the case of the writing system of bahasa Cia-Cia, Seoul Education University, Graduate thesis.

Ladefoged, P \& Maddieson, I. (1996). The Sounds of the world's Languages. Oxford: Blackwell.

Ladefoged, P \& Johnson, K. (2012). A Course in Phonetics. 6th edition. Australia: Wadsworth.

Ladefoged, P. (1993). A Course in Phonetics, New York: Harcourt Brace College Publisher.
La Ino, (2015). Deskripsi Fonologi dan Leksikon Bahasa Cia-Cia, Kajian Linguistik, 12(1). 128.-137.

Lee. H. Y. (1996). Korean Phonetics. Paju: Thaehaksa Press. Lee. H.Y, Hwang .H .S, Abidin. (2009). Bahasa CiaCia 1. Seoul: The Hunminjeongeum Society.

Mustafa Abdullah d.k.k, (1991). Struktur Bahasa Cia-Cia, Jakarta: Departemen Pendidikan dan Kebudayaan.

Safitri. (2014). "Genealogi Bahasa Cia-Cia”. Disertasi, Universitas Gadjah Mada.

Sin, J. Y. (2014). Understanding of Speech, Seoul: Hankookmunwasa Press . (2002). Some Issues in Experimental Phonology of Korean Based on Spoken Language Data, The Association for Korean Linguistics, 17(1), 71.-90.

Sin, J.Y \& Jang, H. J (2006). “An Acoustic Study on the Generational Difference of the Monophthongs in the Daegu Dialect, The Korean Society of Phonetic Sciences And Speech Technology. 57(1), 15.-30.

Yun. E. K. (2011). A Comparison Study of the Vowel Normalization Procedures. The Linguistic Society of Korea, (59), 71.-93.

\section{Internet Portals}

https://www.bps.go.id/news/2015/11/18/127/mengulik-datasuku-di-indonesia.html

http://www.ethnologue.com/show_language.asp? code=cia http://lingtools.uoregon.edu/norm/norm1_help.php.

https://prat.org/ 